\title{
УКРАЇНСЬКА МИСТЕЦТВОЗНАВЧА МЕДІЕВІСТИКА У ВИЩІЙ ШКОЛІ 1960-1980-Х РОКІВ: МЕЖІ МОЖЛИВОГО (РОЗДУМИ НАД НАУКОВИМ ДОРОБКОМ ЯКИМА ЗАПАСКО)
}

\author{
о. 3. Маланчук-Рибак
}

\begin{abstract}
Маланчук-Рибак О. 3. Українська мистецтвознавча медісвістика у вищій школі 19601980-х років: межі можливого (Роздуми над науковим доробком Якима Запаско). У статті проаналізовано суспільно-політичний, культурний та науковий контексти розвитку української мистецтвознавчої медієвістики. Знаковою особистістю у мистецтвознавстві другої половини ХX ст. став професор Яким Запаско. 3'ясовані основні його здобутки як мистецтвознавця-медієвіста, зокрема ті, що стосуються історії української рукописної книги. Основну увагу звернено на проблему можливостей і обмежень української радянської мистецтвознавчої медієвістики.

Ключові слова: мистецтвознавча медієвістика; рукописна книга; Яким Запаско.

Маланчук-Рыбак О. 3. Украинская искусствоведческая медиевистика в высшей школе 1960-1980 гг.: границы возможного (размышления над научным вкладом Якима Запаско). В статье анализируются общественно-политический, культурный и научный контексты развития украинской искусствоведческой медиевистики. Знаковой личностью в искусствоведении второй половины XX в. был профессор Яким Запаско. Определены основные его достижения как искусствоведа-медиевиста, в частности те, что относятся к истории рукописной книги. Основное внимание сосредоточено на проблеме возможностей и ограничений украинской советской искусствоведческой медиевистики.
\end{abstract}

Ключевые слова: искусствоведческая медиевистика; рукописная книга; Яким Запаско.

Malanchuk-Rybak O. Z. Ukrainian Art Medieval Studies in Higher Education of 1960-1980s: the Boundaries of the Possible (Reflections on Scientific Contribution of Yakim Zapasko). The article analyzes the sociopolitical, cultural and scientific contexts of the development of Ukrainian art medieval studies. A prominent person in the art history of the second half of the twentieth century was Professor Yakim Zapasko. His main achievements as a medieval art critic, in particular those concerning the history of the Ukrainian hand-written book, have been found out. The main attention is focused on the problem of the possibilities and limitations of the Ukrainian Soviet art medieval studies.

Keywords: art medieval studies; hand-written book; Yakim Zapasko.

Мистецтвознавчі дослідження вже тривалий час є обов'язковою частиною гуманітарних наук. Ці дослідження мають притаманне їм предметне поле, розвинені методології, наукові школи. Розвинені мистецтвознавчі, зокрема медієвістичні студії, є однією з ознак структурної повноти соціогуманітарних наук. У статті розглядаємо лише одне «предметне поле» мистецтвознавства, а саме - вивчення образотворчого та декоративно-ужиткового мистецтва.

Українське мистецтвознавство розвивалося з деяким часовим «спізненням» порівняно 3 європейським аналізом мистецьких процесів. Але наукові здобутки останніх десятиліть XIX - початку XX ст. дещо «вирівняли» ситуацію. Дослідження Д. Антоновича, О. Голубця, В. Ф. Ернста, В. Залозецького, М. Макаренка, В. Модзалевського, Г. Павлуцького, I. Свенціцького, М. Січинського, С. Таранущенка, Д. Щербаківського, Широцького, Ф. Шмідта та ін. дали підстави говорити про те, що в українському гуманітарному просторі мистецтвознавство (переважно як варіант історії мистецтва) окреслило параметри свого «наукового буття». Подальший розвиток націионального мистецтвознавства відбувався двома шляхами. Перший у контексті «радянської» науки; другий - силами українських дослідників у діаспорі. До 1990-х років ці шляхи практично не перетиналися. Побутує думка, що у тоталітарних державах гуманітарні науки, попавши під ідеологічний прес, перетворюються на знаряддя світоглядних маніпуляцій, а тому якоїсь наукової вартості не можуть мати. Наукову гуманітарну спадщину радянського періоду ігнорують або ж заперечують іiі фаховий рівень. Сьогодні вже з певної часової відстані можна здійснити деяку 
диференціацію, виокремити тих дослідників, які, перебуваючи у вузьких межах можливого, все ж продемонстрували гідний науковий рівень.

Українська мистецтвознавча медієвістика 1960-1980-х років перебувала у конкретному суспільно-політичному, культурному та науковому контекстах, які власне і визначили iii шляхи розвитку та набутки, як, зрештою, і провали, і невдачі.

Суспільно-політичний контекст того часу неоднозначний та суперечливий. 3 одного боку - політична «відлига» другої половини 1950-х - початку 1960-х років, яка принесла відчутні ідеологічні послаблення, що ними відразу скористалися «шістдесятники». Навіть партійна верхівка часом декларувала дивовижно «ліберальні» націоцентричні погляди. Так, П. Шелест, перший секретар ЦК Компартії України, 1970 року видав книжку «Україно наша Радянська», у якій виступив за розвиток української мови, за вивчення національної історії, зокрема козацької минувшини. Щоправда, цей прецедент ліквідували у зародку. Книгу вилучили з продажу та бібліотек, частину накладу знищили; автора ж звільнили з посади, звинувативши в ідеалізації минулого та в обстоюванні самобутності Радянської України. 3 іншого боку - радянський ідеологічний монстр був ще у повній силі й періодично демонстрував гоніння на митців, інтелектуалів та показові розправи над ними. Про ці процеси детальніше писали В. Баран ${ }^{1}$, В. Даниленко ${ }^{2}$ та ін.

Культурний контекст. Панівним варіантом культури був радянсько-український варіант з усіма ідеологічними та художньо-стилістичними атрибутами. У рамках цього глобального радянсько-українського проекту основним завданням було тотальне проникнення у сферу суспільного життя утверджених партійно-ідеологічних норм і приписів. Культура у цьому процесі виконувала не останню роль. Одним з центральних було питання - якою ж має бути українська культура? Відповідь давали на різних рівнях, у різних середовищах. На офіційному державному утвердилась формула про українську культуру як «соціалістичну за змістом, національну за формою», що насправді означало вихолощення самої суті української культури. Має рацію Орест Голубець, стверджуючи, що соцреалізм, як осердя тогочасного мистецтва, «був втіленням глобальної державної політики, виразом неволі, тотального примусу, середовища, в якому непокора і демонстративний вияв власних переконань творця несли безпосередню небезпеку його життю» ${ }^{3}$.

Українські інтелектуали в межах офіційного світоглядного дискурсу робили численні спроби утвердити такий тип національної ідентичності, який поєднав би лояльність до тоталітарної держави та національно-культурне самоствердження. Очевидно, що у такому варіанті національна ідентичність (iї інтелектуальна та мистецька репрезентація) виразно тяжіла власне до фольклорно-етнографічного варіанту.

Модерну українську ідентичність вдалось відчути та репрезентувати небагатьом. Це насамперед митці-нонконформісти. Нонконформізм, культурно-мистецьке дисидентство посідали відносно невеликий сегмент, хоч значення цього сегменту, безумовно, велике. Тогочасним українським інтелектуалам дуже важко давалися спроби синтезувати українство, урбанізм, культурну модерність (не кажучи вже про постмодерність). Обтяжуючим фактором була ізоляція/самоізоляція української культури від загальноєвропейських процесів, інформація про які доходила фрагментарно, несистемно, i, очевидно, була неповною. Культурні контакти зводилися переважно до спілкування між митцями різних радянських республік.

Наполегливо вибудовувалася загальнодержавна культурна ієрархія. Незаперечний пріоритет мав «старший брат» (російський народ та російська культура, мова). Реально діяв принцип двомовності. Російська культура системно та безсоромно привласнювала собі численні культурні здобутки, насамперед українців та білорусів. Державна політика навмисного применшення, знецінення та компрометації, штучного звуження меж української культури велась роками, планово, свідомо, фахово та лукаво. Будь-які протести проти такої політики були приречені на різні форми кари.

Науковий контекст. Очевидно, що гуманітарні науки постійно були під пильним оком державних інституцій, розвинутого до безмежжя цензорства. Щоправда, на мистецтвознавство, мабуть, звертали дещо меншу увагу, ніж, скажімо, на історичні та філологічні науки. Тогочасну мистецтвознавчу медієвістику обмежували низкою чинників. Насамперед йдеться про «ідеологічно-наукове» офіційне трактування суспільно-політичних характеристик, етнічного складу та спадкоємців культури Київської Руси. Державно-політична 
настанова про вибудовування державної та культурної тяглості впродовж Давньоруської держави - Московського царства - Російської імперії та й, зрештою, СРСР діяла безвідмовно, і її використовували повсюдно, вона була обов'язковою історіософською ідеєю для всіх медієвістичних досліджень. Згідно з цією настановою про українців, як про середньовічний етнос, можна було говорити лише починаючи з XIV ст. Зрозуміло, що концепція Михайла Грушевського про безперервну тяглість української історії та культурної традиції і заперечення «общерускої» історії була знайома обмеженому колу читачів бібліотечних та архівних спецфондів, офіційно таврувалася як націоналістична, антинаукова та шкідлива. Межі можливого розвитку мистецтвознавчої медієвістики в Україні були обмежені негласним блокуванням таких важливих наукових напрямів, як візантологія та історія світового, зокрема середньовічного мистецтва. Щоправда, цим напрямам було дозволено розвиватися у російському науковому дискурсі. Сакральне мистецтво, панівне за доби Середньовіччя, з огляду на офіційні тогочасні світоглядно-ідеологічні пріоритети (банальний войовничий атеїзм), апріорі не могло стати повноцінним об'єктом дослідження. Ще одним обмежуючим чинником було табу на методологічні та історіософські новації. Ідеологічно забарвлений позитивізм, як наукова методологія, був тотально домінуючим.

«Відлига» у гуманітарному просторі України опосередковано спричинила появу таких видань, як «Український історичний журнал», «Українська радянська енциклопедія», «Словник української мови», «Історія української літератури», «Історія міст і сіл України». У цьому ж переліку - шеститомна академічна «Історія українського мистецтва». До речі, icторію української культури тоді ж так і не було написано. Щоправда, як своєрідна «компенсація» 3'явилося видання Миколи Марченка «Історія української культури. 3 найдавніших часів до середини XVIII ст.» (1961р.). 3 погляду сьогодення ці видання були типово «радянські», які напередодні виходу у світ не обминуло невсипуще око цензорів. Але, попри дуже істотні обмеження, ці книги витворювали відчуття потужної української «суб’єктності», 3 величезною, навіть за тими обмеженими відомостями, культурною спадщиною.

Об'єктивно існували регіональні особливості української мистецтвознавчої медієвістики, незважаючи на потужне прагнення науковців творити певну наукову цілісність, не розмежовану на окремі культурно-територіальні анклави. Київ - Львів - Харків були науковими та освітніми осередками, де розвивалася мистецтвознавча медієвістика. Львів, мабуть, у цьому сенсі був особливим містом. Тут була надзвичайно потужна джерельна база для мистецтвознавчих досліджень, ще жили «рудименти пам'яті» про доробок заборонених чи неафішованих мистецтвознавців, про історію таких інституцій, як Національний музей, Наукове товариство імені Шевченка, які були справжніми форпостами української культури і мистецтва. Окрім перелічених контекстів, дуже важливими були морально-етичні засади дослідників-медієвістів, які обирали дуже різні стратегії наукової поведінки.

Традиційно мистецтвознавча медієвістика розвивалася у середовищі музейників та архівістів, або ж наукових академічних установ. Адже саме вони зберігали та опрацьовували основний масив мистецьких артефактів. Викладачі вищих навчальних закладів здебільшого переказували, реферували монографічні дослідження. На жаль, повної картини про мистецтвознавчу медієвістику у вищій школі, про навчальні дисципліни, кількість годин, персоналії викладачів не вдалось зібрати в межах всієї України. Тому обмежуюсь лише окремими міркуваннями.

Найбільше можливостей для викладання навчальних курсів, у яких була б репрезентована мистецтвознавча медієвістика, мали так звані мистецькі навчальні заклади, бо там викладали дисципліни «Історія мистецтва», а подекуди навіть «Історія українського мистецтва». Деякі гуманітарні факультети (історичні, філологічні) теж практикували читання таких курсів, щоправда, набагато коротших. Для навчального закладу щасливим збігом обставин було мати викладачів, які б поєднували вміння і талант дослідника музейника/ архівіста з хистом викладача-лектора.

У переліку українських мистецтвознавців-медієвістів, творчість яких припала на 1960 80 рр. багато відомих імен, зокрема Ю. Асєєв, П. Білецький, М. Драган, П. Жолтовський, Г. Логвин, Л. Міляєва, В. Рубан, В. Свенціцька, Д. Степовик, С. Таранущенко, та ін. Доробок кожного з них, безперечно, заслуговує окремого детального, монографічного аналізу. Маємо всі підстави знаковими працями вважати дослідження тогочасного мистецтвознав- 
ця-медієвіста Якима Запаска, який однаково добре репрезентувався у трьох іпостасях - як мистецтвознавець-медієвіст, як високофаховий викладач, як організатор вищої школи.

Без міцного опертя на медієвістичні розвідки Якима Прохоровича Запаска дослідження української культури та мистецтва доби Середньовіччя немислиме. Серед численних статей та монографій ученого найвагомішими $є$ роботи, присвячені українській рукописній книжці та українським стародрукам. Його розвідки мають багаторівневі історіософські, науково-фактологічні, науково-аналітичні, методологічні виміри. Окрім того, ці дослідження мають ще один, дуже важливий вимір - український. Біографія Якима Запаска багато в чому репрезентативна в українській радянській науці. Він народився 1923 р. у с. Росішки на Черкащині в українській селянській родині. Його батько - Прохор Флорович, мати - Фросина Кирилівна, сестри - Ганна, Параска і Текля на глибинному духовно-генетичному, психоемоційному рівнях визначали його українськість. Власне ця «природна» українськість, з роду, із землі, із села була в Я. Запаска дуже особистісною, не декларативною. Водночас це українське самовизначення багато в чому надалі вплинуло на його публічну самореалізацію. На його долю, як і на долю всього покоління, випали «типово українські, радянські» випробування: голодомор, від якого сім'ю врятувала зарадність батька, що перебрався на заробітки до Москви і звідти рятував родину, присилаючи харчі. Деякий час, до весни 1935 р., у Москві перебував малий Яким. Після закінчення школи був покликаний на армійську службу. Під Сталінградом отримав перше поранення, лікувався. Знову фронт. Війна для нього скінчилася у Польщі 1944 р. через важке поранення у голову. Рік у госпіталі. Демобілізація.

Такий початок життя міг по-різному вплинути на молодого чоловіка. На щастя, Я. Запаско мав неабияку волю до життя, амбітні плани і, напевне, скористався поблажливістю Долі. Він став студентом-фронтовиком у Львівському поліграфічному інституті імені Івана Федорова. Уже там сформувалася основна сфера його професійного зацікавлення - українська книга. Він зреалізував себе і як практик, зокрема, як редактор Львівського книжково-журнального видавництва, працюючи над художнім оздобленням книг. Але невдовзі перейшов на наукову роботу, спочатку у Львівський музей етнографії і художнього промислу АН України, а з 1958 - на посаду ректора Львівського інституту прикладного та декоративного мистецтва (з 1994 р. - Львівська національна академія мистецтв).

Така щаслива життєва дорога судилася небагатьом. Але й дуже мало серед цих небагатьох скористались життєвим шансом і не лише зреалізували особисту успішну кар'єру, а й дали потужний імпульс для розвитку української культури, науки, історичної пам'яті. Очевидно, що науковий вибір Я. Запаска на початку кар'єри був пов'язаний з історично-політичним контекстом («відлига» 1960-х років і певне послаблення ідеологічних обмежень у національному питанні), а також культурно-регіональними особливостями повоєнного Львова (колишній фронтовик, виходець із Центральної України, можливо, обираючи «національну» тему наукових досліджень, і не мав аж такого великого страху перед державно-ідеологічним Молохом, як багато хто 3 «місцевих»).

Мистецтвознавча медієвістика у науковому доробку Я. Запаска всебічно репрезентована у дослідженнях рукописної книги, ії мистецького оформлення ${ }^{4}$. Уже перше вагоме дослідження - кандидатська дисертація мала назву «Орнаментальне оформлення української рукописної книги». Робота була захищена у 1958 р. в Москві. 1960 р. на основі дисертації він видав однойменну монографію. Очевидно, що у цій книзі були обов'язкові слова про «братній» російський народ, про спільне походження східнослов'янських народів. До речі, і в наступних численних статтях і монографіях при бажанні можна відшукати й таке немиле нам «на Україні», і термінологічну невпорядкованість. Наприклад, як синоніми вживав Давня Русь (данина російській історіографічній традиції) і Київська Русь; а також київські, давньоукраӥнські, старослов'янські, давньоруські, південноруські пам'ятки. Треба враховувати, що на той час (та й, зрештою, і дотепер) основна література, у якій досліджували рукописну книгу, була російськомовна з виразною ідеологічно-пропагандистською домінантою, а саме - намаганням зафіксувати вже з ХІ ст. тотальне «русское книгописание». На цьому фоні вперто звучало Запаскове - київські, південноруські, українські рукописні книги. Власне ця ідея - регіонального розмежування і чіткої культурноетнічної ідентифікації української рукописної книги - була однією з основних наукових ідей Я. Запаска. Як вже відзначено, загальноприйнятим у радянській науці було датування 
початків української культури з XIV ст. I суперечити цій ідеологічній настанові вистачало відваги дуже небагатьом. Дослідник вже на початку наукового шляху окреслив поле свого наукового інтересу - українська рукописна книга як цілісне культурно-мистецьке явище XI-XVIII ст. I такий підхід мав свої сильні та слабкі сторони. Аналітичний розум дослідника дав змогу максимально раціонально структурувати весь масив фактологічного матеріалу, побудувати вивірену за художньо-стилістичними ознаками періодизацію. Очевидно, що найуразливішим місцем такого підходу була надто велика кількість, особливо у XVII-XVIII ст., рукописних книжок, які вимагали глибокого аналізу автора. Першопочатки рукописної книги Я. Запаско досліджує особливо докладно, кожна збережена книжка потрапила в поле його зору, натомість до пізніших зразків, доби Ренесансу та Бароко, застосовує принцип репрезентаційного відбору. Згодом, 1971 р. професор видав монографію «Мистецтво книги на Україні в XVI-XVIII ст.» ${ }^{5}$, у якій звернувся до українських стародруків. Власне у цьому дослідженні художнє оформлення друкованої книжки показано як продовження мистецьких процесів, пов'язаних з рукописною книгою, а стародруки потрактовано як один з важливих і обов'язкових елементів української культури. Ще одна дуже важлива ідея, що пронизує дослідження Я. Запаска, - це надзвичайно аргументоване твердження про тяглість, безперервність культурно-історичного розвитку різних українських земель. До речі, його прецизійний аналіз рукописних книг об'єктивно заперечує теорію Погодіна про обезлюднення центрально українських земель після татаро-монгольської навали. Дослідник послідовно дотримується ідеї культурно-етнічної єдності України та безперервності іiї історії. I скрізь домінує надзвичайно важливий аспект українського виміру наукових досліджень Я. Запаска - періодизація мистецтва рукописної книги в Україні. Дослідження рукописної книги, зокрема ії мистецького оформлення, здавалось би, не передбачало надто великої уваги до визначення і характеристики основних культурно-історичних періодів. Але періодизація за особливостями художньо-мистецьких стилів у Я. Запаска збігається із згаданою загальноісторичною періодизацією, запропонованою М. Грушевським у статті «Звичайна схема «русскої» історії й справа раціонального укладу історії східного слов'янства» ${ }^{6}$. Основні положення М. Грушевського про надуманість і фальшивість тези щодо існування загальноросійської, або східнослов'янської історії (а ця теза офіційно була прийнята і в радянській науці) дослідження Я. Запаска повністю підтверджують. Хоча самого М. Грушевського дослідник не цитував.

1995 року виходить у світ монографія Я. Запаска «Пам'ятки книжкового мистецтва. Українська рукописна книга», що стала підсумком його медієвістичних досліджень. Видання, безумовно, готувалося задовго до видруку. Саме тут співмірно поєднано власне мистецтвознавчий аналіз із усебічним з'ясуванням культурно-історичного контексту. У цьому дослідженні Я. Запаско реалізував тогочасні європейські історіософські засади медієвістики, хоч ніколи не цитував відомих європейських дослідників. Я далека від думки про запозичення ним певних методологічних засад, хоч у 1990-х роках в Україні вчені активно відкривали для себе нові, невідомі їм історіософські та методологічні підходи. Я. Запаско не був ретроградом у питаннях методології. Він здійснив дослідження на мікрорівні, зокрема, однієї книги (Київський псалтир), чи одного автора (наприклад, Андрійчини). Поєднав мистецтвознавство, палеографію, історію мови та порівняльне мовознавство. Увагу науковець не лише зафіксував на художньо високовартісних книжкових мініатюрах, а й з'ясував «дрібні», малопомітні деталі, а також показав на не надто вправні твори тогочасних майстрів. А саме на таких засадах будувалася європейська та й світова медієвістика. До речі, розгляд історії української рукописної книги (явища суто середньовічного) аж до XVIII ст. дуже подібний до ідеї про так зване Довге Середньовіччя найвідоміших європейських медієвістів. Дослідникові вдалося гармонійно поєднати прискіпливість ученого-фактографа і переконливість аналітика. Він надзвичайно уважний до різних аспектів історії рукописних книг (місце появи, місце зберігання, авторство, особливості письма та мови, деталі художнього оздоблення та ін.).

Водночас не менш суттєві для нього і концептуальні питання. Одним з таких було згадане вже регіональне розмежування руських літописів. Добрі $є$ ті дослідження, які не лише дають вичерпні відповіді на поставлені питання, а й чітко формулюють ще не вирішені наукові проблеми. Власне Я. Запаско був серед тих, хто поставив проблему величезних втрат, пограбувань української рукописної книжки, стародруків ${ }^{7}$. Значна частина 
культурно безцінних пам'яток різними шляхами, правдою і неправдою потрапляли до Росії і зберігалися не лише в офіційних інституціях, а й у приватних колекціях. Доступ до оригіналів у нинішній ситуації майже неможливий. Особливо важливим Я. Запаско вважав збереження та наукову каталогізацію раритетів. До цієї справи він сам фахово долучився. У співавторстві з Ярославом Ісаєвичем видав три томи «Пам'ятки книжкового мистецтва. Каталог стародруків, виданих на Україні» (1981-1984). А у згаданому виданні «Пам'ятки книжкового мистецтва. Українська рукописна книга», окрім монографічної частини, є грунтовний опис 128 рукописів. Досліджуючи історію української книги, Я. Запаско спирався на доробок насамперед українських учених кінця XIX - першої половини XX ст. (Я. Головацький, О. Колесса, І. Свєнціцький, І. Огієнко, П. Жолтовський, В. Пуцко, О. Мацюк та ін.). Але все ж основна література, на яку покликався, з якою деколи полемізував, належала російським дослідникам. Професор очевидно добре розумів ту колосальну диспропорцію у вивченні рукописної книги, зокрема української, яка існувала між російськомовною та україськомовною історіографією. Власне його творчість і була дуже успішною спробою хоча б частково подолати цю диспропорцію.

Повертаючись до теми наукової фаховості, треба сказати, що його робота над працями попередників і сучасників може слугувати прикладом. Посилання на доробок інших дослідників ніколи не було формальністю, Я. Запаско завжди демонстрував глибоку пошану до вже зробленого. Його цитування доречні та продумані. Водночас Я. Запаско вів постійну полеміку з приводу дискусійних питань. А будучи абсолютно переконаним у правильності своїх засад, обирав полемічно гострий, емоційний тон для публікацій. Так було у випадку з російським вченим Г. Вздорновим, який твердив, що «Київський псалтир» належить до пам'яток московської писемності. Аналізуючи такі твердження, учений дотримувався академічного канону. На тлі наукового доробку Я. Запаска сьогоднішні вимоги до досліджень у гуманітарній сфері (обов'язкове використання іншомовної, насамперед англомовної літератури, апробованих західними дослідниками методологій, вираховування різноманітних індексів цитування та ін.) видаються дещо дріб'язковими, надмірно формалізованими. Ще кілька фактів, які, як на мене, дуже промовисто характеризують український вимір Я. Запаска - науковця і педагога. Перший - його володіння рідною мовою. Послуговувався вишуканою, добірною літературною українською мовою. А Львівський інститут декоративного та прикладного мистецтва у часи його ректорства був українськомовним за будь-яких політичних обставин. Другий факт - 1990 р. $з$ його ініціативи в Інституті було введено для всіх факультетів навчальний курс «Історія української культури», окрім давнішого «Історія українського мистецтва». Відповідно до цих курсів видавалися навчальні посібники, які грунтувалися на монографіях Я. Запаска. Третій - 3 його ініціативи 1994 р. розпочала роботу Вчена рада по захисту кандидатських та докторських дисертацій з мистецтвознавства, яка успішно працює й досі.

У 1990-х почав говорити зі студентами, колегами, земляками про Голодомор, який сам пережив. Це була його дуже особистісна вистраждана та пережита данина пам'яті загиблим у 1930-ті роки.

І на завершення ще кілька міркувань. Перечитуючи книжки, статті Я. Запаска, вже не раз замислююсь над питанням про, як прийнято казати, «наукові здобутки радянського часу». У своїх судженнях ми, сучасники, часто висловлюємо дуже однобокі оцінки. Поширеним, майже усталеним $є$ заперечення наукової вартості радянського доробку у гуманітаристиці. Мовляв, у тогочасних авторів ідеологія переважала над наукою і так іiї деформувала, що шкода часу на ії вивчення. Найінтенсивніше «вимивання» радянської науки відбувається на рівні викладання у вищій школі, проникло воно і на рівень багатьох сучасних дисертаційних робіт, де згадки про радянські видання в історіографічних оглядах формальні, без глибокого проникнення у суть дослідження. На щастя, сучасна українська академічна медієвістика уникла тотального «викриття» ідеологізованої радянської науки. При читанні деяких спогадів, публіцистичних розвідок, навіть наукових досліджень складається враження, що автори хочуть переконати в тому, що українськість - це протест, підпілля, антидержавна позиція, нонконформізм. А поза тим суцільне пристосуванство, служіння антиукраїнській владі, зрада та угодовство. I як висновок - українська справа, якщо і розвивалася, то лише всупереч тогочасній владі. Такі погляди, на моє переконання, тотально блокують сам процес з'ясування найрізноманітніших процесів радянської історії. 
Український вимір радянського часу дуже багатогранний та неоднозначний. Це й безсумнівні здобутки «високої» культури, науки, мистецтва, власне тих інтелектуалів, серед яких був Я. Запаско. I, зрештою, життя та праця тисяч учителів, викладачів, лікарів, бухгалтерів та інженерів, науковців, зрештою робітників і селян, що працювали у ненависних для нас колгоспах. Ці люди не боролись із системою, відкрито не протестували проти неї. Вони працювали в заданій системі ідеологічних координат, але були українцями, при цьому дуже різними. Завдяки ним маємо право стверджувати, що українська культура все-таки мала тяглість розвитку та виявляла поступ. А радянський період, при всій його страхітливій тоталітарній безнадійності, має виразний людський український вимір. Чи був Яким Запаско частиною системи? Так, був, i, як на мене, нема потреби вишукувати щось, що він робив усупереч системі, якийсь його внутрішній нонконформізм. Це невдячна справа. Яким Запаско був частиною свого часу, одним з його численних індивідуальних часопросторів. Час визначав його, але і він визначав дуже конкретний історичний час. Люди не обирають історичного часу для свого життя. Але мають можливість вибудувати систему координат своєї порядності, доброчесності, фаховості, зрештою культурно-національної ідентичності. Науковий вимір його Особистості був вивірений, сталий, незмінний та принциповий.

${ }^{1}$ Баран В. Україна після Сталіна: Нарис історії 1953-1985 pр. Львів, Свобода, 1992. 124 с.

${ }^{2}$ Баран В., Даниленко В. Україна у умовах системної кризи (1946-1980-і рр.). Київ: Альтернативи, $1999.304 \mathrm{c}$.

${ }^{3}$ Голубець О. Мистецтво ХХ століття: український шлях. Львів, 2012. С.63.

${ }^{4}$ Запаско Я. П. Орнаментальне оформлення української рукописної книги. Київ: АН УРСР, 1960. 184 с.; Запаско Я. П. Ошатність української рукописної книги. Львів, 1998. 150 с.; Запаско Я. П. Пам’ятки книжкового мистецтва. Українська рукописна книга. Львів: Світ, 1995. 480 с.

5 Запаско Я. П. Мистецтво книги на Україні в XVI - XVIII ст. Львів: В-во Львівського університету, $1971.310 \mathrm{c}$.

${ }^{6}$ Грушевський М. С. Звичайна схема «русскої» історії й справа раціонального укладу історії східного слов'янства / М. Грушевський // Твори: у 50 т. Львів, 2002. Т. 1: Серія «Суспільно-політичні твори», 1894-1907. С. 75-82.

7 Запаско Я. П. Українська рукописна книга за кордоном (до питання про повернення в Україну культурних цінностей) // Альманах. 1994: Мистецький науково-популярний ілюстрований щорічник. Львів, 1995. С. 38-44. 